Healthcare Nursing Journal - vol. 4 no. I (2022) Hal I79-I93

\title{
DUKUNGAN KELUARGA DAN PERSONAL HYGIENE PADA PASIEN STROKE DI RUMAH SAKIT MITRA HUSADA PRINGSEWU
}

\section{Nur Fadhilah', Lusiyana Pangestuti², Rani Ardina³}

1,2,3 Universitas Muhammdiyah Pringsewu Lampung

Article Information

Received: Agustus 2021

Revised: November 2021

Available online : Januari 2022

Keywords

Dukungan keluarga, Personal hygiene, Stroke

\section{Correspondence}

Phone: (+62) 812-6084-1271

E-mail:fadhil@umpri.ac.ai

\section{ABSTRACT}

Stroke merupakan penyebab umum kematian ke tiga di Negara maju setelah penyakit kardiovaskular dan kanker. Stroke terjadi karena ada gangguan aliran darah ke bagian otak. Bentuknya dapat berupa lumpuh sebelah (hemiplegia), berkurangnya kekuatan sebelah anggota tubuh (hemiparesis), akibat lanjut pasien mengalami gangguan kebersihan diri (personal hygiene). Dorthea Orem menjelaskan bahwa perawatan diri merupakan kegiatan memenuhi kebutuhan dalam mempertahankan kehidupan, kesehatan dan kesejahteraan individu baik dalam keadaan sehat maupun sakit. Model Orem diperluas dari perawatan individu menjadi perawatan keluarga. Salah satu faktor yang mempengaruhi kebutuhan pemenuhan kebersihan diri menurut Orem adalah sistem keluarga. Tujuan penelitan ini adalah diketahuinya hubungan dukungan keluarga dengan personal hygiene pada pasien stroke di Ruang Rawat Inap Rumah Sakit Mitra Husada Pringsewu Tahun 2020. Jenis penelitian ini menggunakan metode analitik dengan pendekatan cross sectional. Populasi berjumlah 83 orang dan sampel 69 orang dengan teknik sampling accidental sampling. Alat pengumpul data menggunakan kuesioner dan lembar observasi kemudian dianalisis menggunakan chi square. Hasil penelitian menunjukkan bahwa terdapat hubungan yang signifikan ( $p$-value $=0,000$ ) dukungan keluarga dengan personal hygiene pada Pasien Stroke. Pemberian perawatan yang komprehensif sebaiknya melibatkan peran serta keluarga, hal ini sejalan dengan tugas keluarga yaitu memberikan perawatan pada angota keluarga yang mengalami masalah kesehatan. 


\section{PENDAHULUAN}

Stroke merupakan salah satu jenis penyakit tidak menular, merupakan penyebab umum kematian ke tiga di Negara maju setelah penyakit kardiovaskular dan kanker. Stroke adalah penyakit gangguan fungsional pada otak yang bersifat akut. Stroke merupakan penyakit pembuluh darah otak dengan tanda dan gejala yang muncul sesuai bagian otak yang terserang. Stroke masih menjadi masalah kesehatan prioritas di dunia dan di Indonesia yang mempengaruhi mortalitas dan morbiditas penduduk dengan prevalensi yang cukup tinggi (Wurtiningsih, 2012).

Secara global 15 juta orang terserang stroke setiap tahunnya, satu pertiga meninggal dan sisanya mengalami kecacatan permanen yaitu 33 juta dan menjadi penyebab utama kecacatan pada orang dewasa (Stroke Association, 2015). Data WHO (World Health Organization) menyebutkan terdapat 17 juta kasus stroke baru yang tercatat tiap tahunnya, dan 7 juta kematian akibat stroke. Prevalensi stroke di Indonesia mengalami peningkatan setiap tahunnya. Data South East Asian Medical Information Centre (SEAMIC) menginformasikan bahwa angka kematian stroke terbesar terjadi di Indonesia, diikuti oleh Filipina, Singapura, Brunei, Malaysia, dan Thailand (WHO, 2013).

Riskesdas

Tahun

2018

menginformasikan prevalensi stroke mengalami kenaikan jika dibandingkan dengan Riskesdas 2013. Penyakit stroke juga menjadi penyebab kematian utama hampir seluruh Rumah Sakit di Indonesia tahun 2013 dengan angka kematian berkisar 12,1\%, sebanyak 57,9\% penyakit stroke telah terdiagnosis oleh tenaga kesehatan (nakes). Prevalensi stroke naik dari $7 \%$ menjadi 10,9\%, hal ini berhubungan dengan bertambahnya umur, pola hidup, merokok, konsumsi minuman beralkohol, aktivitas fisik, serta kurangnya konsumsi buah dan sayur (Kemenkes RI, 2018).

Stroke terjadi karena ada gangguan aliran darah ke bagian otak. Bila ada daerah otak yang kekurangan pasokan darah secara tiba-tiba dan penderitanya mengalami gangguan sistem syaraf sesuai daerah otak yang terkena. Bentuknya dapat berupa lumpuh sebelah (hemiplegia), berkurangnya kekuatan sebelah anggota tubuh (hemiparesis), gangguan bicara, gangguan rasa (sensasi) di kulit sebelah wajah, lengan atau tungkai (Kemenkes RI, 2018), akibat lanjut pasien mengalami gangguan 
kebersihan diri (personal hygiene). Personal hygiene sangat dipengaruhi oleh nilai individu dan kebiasaan sehingga personal hygiene merupakan hal penting dan harus diperhatikan karena personal hygiene akan mempengaruhi kesehatan dan psikis seseorang, selain itu pemeliharaan personal hygiene diperlukan untuk kenyamanan individu, keamanan, dan kesehatan (Tarwoto \& Wartonah, 2012).

Penelitian Pertiwi (2012) di Rumah Sakit Muhammadiyah Yogyakarta diperoleh gambaran bahwa 40\% dari 47 pasien stroke mengatakan tidak dibantu untuk mandi, menggosok gigi, dan membersihkan mulut, $42 \%$ menyatakan tidak pernah membersihkan atau memotong kuku, serta $42 \%$ tidak pernah dibantu untuk membersihkan atau merapikan rambut. Sejalan dengan penelitian Rahmatika penelitian yang dilakukan pada tanggal 4 April 2012 di Rumah Sakit Dr. Soeparun Malang, dari 5 pasien stroke 3 (60\%) diantaranya tidak mendapatkan dukungan keluarga dan 5 pasien stroke 4 (80\%) tidak dibantu dalam pelaksanaan personal hygiene. Sementara Naziyah (2019) menginformasikan bahwa usia dan dukungan keluarga mempunyai pengaruh dengan personal hygiene, lebih lanjut Wurtiningsih (2012) menegaskan bahwa peran dan dukungan keluarga diperlukan dalam memenuhi personal hygiene pada pasien stroke di Ruang Rawat Inap.

Dampak terburuk ketika kebersihan diri tidak terpenuhi terutama pada pasien stroke adalah gangguan fisik berupa gangguan integritas kulit, gangguan membran mukosa mulut, infeksi pada mata dan telinga, dan gangguan pada kuku. Tidak terpenuhinya kebutuhan personal hygiene juga berdampak pada psikososial yang berhubungan dengan imobilisasi. Gangguan tersebut meliputi gangguan rasa nyaman, kebutuhan dicintai dan mencintai, kebutuhan harga diri, aktualisasi diri dan gangguan interaksi sosial (Wartonah, 2010).

Menurut teori Dorthea Orem perawatan diri merupakan kegiatan memenuhi kebutuhan dalam mempertahankan kehidupan, kesehatan dan kesejahteraan individu baik dalam keadaan sehat maupun sakit. Model Orem diperluas dari perawatan individu menjadi perawatan keluarga dan keluarga dibutuhkan jika seorang dewasa tidak mampu melaksanakan perawatan perawatan diri secara memadai untuk memepertahankan kehidupan, memelihara kesehatan, atau penyakit. Faktor yang mempengaruhi kebutuhan pemenuhan 
kebersihan diri menurut Orem diantaranya usia, jenis kelamin, status perkembangan, status kesehatan, sosiokultural, sistem pelayanan kesehatan, sistem keluarga, pola hidup, lingkungan, dan ketersediaan sumber (Akbar, 2019).

Salah satu faktor yang mempengaruhi kebutuhan perawatan diri menurut Orem adalah sistem keluarga yaitu keluarga dapat melakukan atau menjalankan perawatan diri yang meliputi sikap mengenai kesehatan mereka dan kemampuan mereka untuk melaksanakan perilaku perawatan diri, hal tersebut yang menjadikan dukungan keluarga dibutuhkan apabila individu tidak dapat melakukan pemenuhan kebersihan diri (Friedman, 2014).

Bedasarkan data pasien Rawat Inap di RS Mitra Husada Pringsewu, pasien yang mengalami stroke pada Tahun 2018 sebanyak 708 pasien, pada Tahun 2019 Bulan Januari September sebanyak 679 pasien. Pasien stroke yang Rawat Inap dalam 3 bulan terahir di Rumah Sakit Mitra Husada Pringsewu mengalami peningkatan dari Bulan Juli sebanyak 54 pasien Bulan Agustus 67 pasien dan pada Bulan September sebanyak 83 pasien. Hasil prasurvey pasien stroke yang berada di ruang rawat inap di RS Mitra
Husada, dari 10 pasien 7 diantaranya mengalami gangguan kebersihan diri, terlihat dari penampilan klien yang tidak rapi, pasien tampak tidak segar, bau, rambut terlihat berantakan, pakaian tampak kotor dan tidak pernah berganti pakaian, tidak menggosok gigi dan kuku terlihat kotor. Klien mengatakan tidak dibantu untuk melakukan kebersihan diri padahal keluarga pasien selama 24 jam berada di samping pasien. Keluarga hanya berfokus pada proses pengobatan pasien tanpa memperhatikan kebersihan diri pasien. Dari masalah tersebut maka peneliti tertarik untuk melakukan penelitian tentang hubungan dukungan keluarga dengan personal hygiene pada pasien stroke di Ruang Rawat Inap Rumah Sakit Mitra Husada Pringsewu .

\section{METODE PENELITIAN}

Metode penelitian menggunakan studi analitik dengan rancangan cross sectional. Adapun variabel dalam penelitian ini terdiri dari variabel independen (bebas) adalah variabel ang mempengaruhi atau yang menjadi sebab perubahannya atau timbulnya variable dependen (Sugiyono, 2013). Variabel independen dalam penelitian ini adalah dukungan keluarga. Populasi dalam penelitian ini adalah pasien stroke pada bulan April 
2020 di Ruang rawat inap Rumah Sakit Mitra Husada Pringsewu sebanyak 83 pasien. Sampel Sampel dalam penelitian ini adalah pasien stroke pada bulan April 2020 di Ruang rawat inap Rumah Sakit Mitra Husada Pringsewu. Metode pengumpulan data dilakukan dengan melakukan wawancara langsung kepada responden yang telah memenuhi kriteria. Pengolahan data dilakukan melalui empat tahap sebagai berikut: Editing, Coding, Prosesing,dan Cleaning.

HASIL DAN PEMBAHASAN

Tabel 1

Distribusi Frekuensi Responden Berdasarkan Karakteristik

\begin{tabular}{ccc}
\hline Umur & Frekuensi & Presentase (\%) \\
\hline $\begin{array}{c}\text { 45-60 tahun } \\
\geq 61 \text { tahun }\end{array}$ & 29 & 42.0 \\
Jenis Kelamin & 40 & 58.0 \\
\hline Laki laki & 38 & 55.1 \\
Perempuan & 31 & 44.9 \\
Pendidikan & & \\
\hline SD & 45 & 65.2 \\
SMP & 17 & 24.6 \\
SMA & 7 & 10.1 \\
Pekerjaan & & \\
\hline Petani & 30 & 43.5 \\
IRT & 13 & 18.8 \\
Wiraswasta & 17 & 24.6 \\
Tidak bekerja & 9 & 13.0 \\
Jumlah & $\mathbf{6 9}$ & $\mathbf{1 0 0}$ \\
\hline Tabel 1 menjelaskan bahwa & lebih dari
\end{tabular}

Tabel 1 menjelaskan bahwa lebih dari sebagian besar responden berumur $\geq 61$ tahun yaitu 40 respoden (58.0\%), berjenis kelamin laki-laki 38 respoden (55,1\%), berpendidikan SD 45 responden $(65,2 \%)$ dan 30 responden (43,5\%) bekerja sebagai petani.

Tabel 2

Distribusi Frekuensi Responden Berdasarkan Dukungan Keluarga

Dukungan Keluarga Frekuensi Presentase

\begin{tabular}{ccc}
\hline Kurang & 34 & 49.3 \\
Baik & 35 & 50.7 \\
\hline Jumlah & 69 & 100 \\
\hline
\end{tabular}

Tabel 2 menjelaskan bahwa lebih dari sebagian besar responden mendapat dukungan keluarga dengan kategori baik yaitu sebanyak 35 responden (50,7\%).

Tabel 3

Distribusi Frekuensi Responden Berdasarkan Personal Hygiene

Personal Hygiene Frekuensi Presentase

\begin{tabular}{ccc}
\hline Baik & 36 & 52.2 \\
Kurang Baik & 33 & 47.8 \\
\hline Jumlah & 69 & 100 \\
\hline
\end{tabular}

Tabel 3 menjelaskan bahwa lebih dari sebagian besar personal hygiene dalam kategori baik yaitu 36 responden (52,2\%).

Tabel 4 Hubungan Dukungan Keluarga Dengan Personal Hygiene Pada Pasien Stroke

\begin{tabular}{|c|c|c|c|c|c|c|c|c|}
\hline \multirow{3}{*}{$\begin{array}{c}\text { Dukungan } \\
\text { keluarga }\end{array}$} & \multicolumn{4}{|c|}{ Personal Hygiene } & \multicolumn{2}{|c|}{ Total } & $\begin{array}{c}\mathrm{P} \\
\text { Value }\end{array}$ & $\begin{array}{c}\text { OR } \\
95 \% \mathrm{CI}\end{array}$ \\
\hline & \multicolumn{2}{|c|}{$\begin{array}{c}\text { Kurang } \\
\text { baik }\end{array}$} & \multicolumn{2}{|c|}{ Baik } & & & & \\
\hline & $\mathrm{N}$ & $\%$ & $\mathrm{~N}$ & $\%$ & $\mathrm{~N}$ & $\%$ & & \\
\hline Kurang & 32 & 94.1 & 1 & 2.9 & 33 & 100 & 0.000 & 53.374 \\
\hline Baik & 2 & 5.9 & 34 & $\begin{array}{c}97 . \\
1 \\
\end{array}$ & 36 & 100 & & $\begin{array}{c}8.562 \\
332.718\end{array}$ \\
\hline Jumlah & 34 & 100 & 35 & 100 & 69 & 100 & & \\
\hline
\end{tabular}


Tabel 4 menginformasikan bahwa responden dengan dukungan keluarga kurang, 32 kali lebih banyak menunjukkan personal hygiene kurang baik. Sementara responden dengan dukungan keluarga baik, 17 kali lebih banyak menunjukkan personal hygine baik. Hasil uji statistik didapatkan nilai p-value $0,000<0,05$. Dapat dapat disimpulkan ada hubungan antara dukungan keluarga dengan personal hygiene pada pasien stroke di Rumah Sakit Mitra Husada Pringsewu Tahun 2020, dengan nilai OR 53.374 yang keluarga yang kurang memberikan dukungan memiliki resiko 53.374 kali penampilan personal hygiene yang kurang.

Bedasarkan analisis penelitian menjelaskan bahwa sebagian besar responden berumur $\geq 61$ tahun yaitu 40 respoden (58.0\%), hal ini menunjukkan bahwa usia merupakan faktor risiko stroke, semakin tua usia maka risiko terkena stroke akan semakin tinggi. Meskipun stroke dapat menyerang segala usia, diketahui bahwa mereka yang berusia lanjut lebih berisiko terserang penyakit yang berpontensi mematikan dan menimbulkan kecacatan menetap (Genis, 2011).
Bedasarkan jenis kelamin laki-laki yaitu 38 respoden $(55,1 \%)$, hasil analisis ini sesuai dengan pendapat yang dikemukakan oleh Meiwanto (2013) bahwa stroke lebih banyak mengenai pria dari pada wanita, risiko terkena stroke pada pria lebih tinggi dari pada wanita sampai usia 70 tahun. Bedasarkan anaisis penelitian sebagian besar responden berpendidikan SD yaitu sebanyak 45 responden $(65,2 \%)$ dan 30 responden (43,5\%) bekerja sebagai petani. Hasil ini didukung oleh teori Notoatmodjo (2010) bahwa pengetahuan dan pendidikan merupakan faktor predisposisi yang dapat mempengaruhi status kesehatan manusia. Tingkat pengetahuan yang rendah mengenai penyakit dan bagaimana proses pemulihan. Pendidikan merupakan salah satu faktor yang dapat menyebabkan terhambatnya proses pemulihan.

Bedasaarkan hasil analisis penelitian menunjukkan bahwa dukungan keluarga baik yaitu sebanyak 35 responden (50,72\%) lebih besar dari dukungan keluarga kurang yaitu 34 respoden $(49,28 \%)$. Hal ini membuktikan bahwa keluarga bertanggung jawab mempengaruhi setiap aspek perawatan kesehatan anggota keluarga dan merupakan sistem pendukung utama yang memberikan 
perawatan langsung pada setiap keadaan sehat-sakit.

Dukungan adalah suatu upaya yang diberikan kepada orang lain, baik moril maupun materil untuk memotivasi orang tersebut dalam melaksanakan kegiatan. Dukungan keluarga juga didefinisikan sebagai informasi, saran, bantuan yang nyata yang diberikan oleh orang-orang yang akrab berupa kehadiran dan hal-hal yang dapat memberikan keuntungan emosional dan berpengaruh pada tingkah laku penerimanya (Sarwono, 2011). Dalam hal ini orang yang merasa memperoleh dukungan secara emosional merasa lega karena diperhatikan, mendapat saran atau kesan yang menyenangkan pada dirinya, seperti keluarga memberi semangat dan pujian pada pasien stroke untuk melakukan pemenuhan kebersihan diri.

Dukungan keluarga biasanya didapatkan dari orang terdekat yang dapat dipercaya, sehingga seseorang akan tahu bahwa ada orang lain yang memperhatikan, menghargai dan mencintainya. Selama perawatan di Rumah Sakit keluarga memiliki peran untuk turut andil dalam pemenuhan kebutuhan pasien baik dalam bentuk materi, dukungan maupun semangat. Keluarga berperan penting dalam upaya meningkatkan kemampuan pasien untuk mandiri, meningkatkan rasa percaya diri pasien, dan meminimalkan agar tidak menambah masalah kesehatan (Friedman, 2013). Penelitian yang berhubungan dengan dukungan keluarga juga pernah dilakukan oleh Allo (2015), tentang dukungan keluarga dalam merawat pasien stroke di ruang rawat interna RSUD Lakipadada.

Penelitian ini juga sejalan dengan penelitian Wurtiningsih (2012), bahwa dukungan keluarga berperan sangat penting untuk membantu dalam proses penyembuhan dan rehabilitasi pasien yang sangat membutuhkan waktu yang lama sehingga membutuhkan dukungan keluarga. Dukungan informasional yang diberikan keluarga memperlihatkan bahwa penyakit yang diderita pasien adalah stroke. Beberapa bentuk perhatian juga diberikan keluarga sebagai bentuk dukungan emosional. Keluarga juga memberikan dukungan instrumental, seperti membantu rentang gerak sendi, dan membantu pasien selama melakukan pengobatan. Sedangkan dukungan penghargaan pada umumnya diberikan keluarga dalam bentuk sikap dan perhatian. 
Berdasarkan hasil analisis penelitian, maka dapat disimpulkan bahwa dibutuhkan kesadaran keluarga yang tinggi akan pentingnya dukungan kepada anggota keluarga yang sakit terutama dalam memenuhi kebersihan diri. Dukungan keluarga penting untuk diberikan kepada anggota yang sakit karena pada orang yang sakit mengalami keterbatasan, yang menyebabkan pasien membutuhkan dukungan orang lain terutama keluarga untuk memenuhi kebutuhannya dan selayaknya semua jenis dukungan tersebut dapat diterima oleh anggota keluarga yang sakit salah satunya tindakan pemenuhan kebersihan diri.

Berdasarkan analisis penelitian personal hygiene bahwa, sebesar 36 responden (52,2\%) personal hygiene baik dan sebanyak 33 responden (47,8\%) personal hygiene kurang baik. Hal ini membuktikan bahwa masih ada pasien yang tidak memperhatikan kebersihan diri (personal hygiene) tetapi lebih banyak yang melakukan kebersihan diri.

Secara normal orang dewasa mampu merawat dirinya sendiri, tetapi orang sakit, lansia, bayi, anak anak membutuhkan penuh atau dibantu dalam kegiatan perawatan diri.
Menurut hierarki kebutuhan manusia Maslow kebersihan diri menempati tingkat pertama atau dasar yaitu kebutuhan fisiologis dimana yang pertama kali harus dipenuhi. Mashlow memberi hipotesis bahwa setelah kebutuhan individu pada tingkat paling bawah terpenuhi, maka kebutuhan pada tingkat yang berikutnya akan dipenuhi juga. Jika pada tingkat tertinggi tetapi kebutuhan dasar tidak terpenuhi maka individu kembali pada tingkat kebutuhan yang sebelumnya (Friedman, 2014).

Menurut teori Dorothea Orem, Perawatan diri adalah kegiatan memenuhi kebutuhan dalam mempertahankan kehidupan, kesehatan dan kesejahteraan individu baik dalam keadaan sehat maupun sakit yang berkembang dari perawatan individu menjadi perawatan keluarga (Akbar, 2019).

Personal hygiene penting karena personal hygiene yang baik akan meminimalkan pintu masuk (port de entry) mikroorganisme yang ada dimana-mana dan pada akhirnya mencegah seseorang terkena penyakit. Jenis jenis personal hygiene meliputi kebersihan kulit, kebersihan rambut, kebersihan gigi, kebersihan mata, kebersihan telinga, kebersihan tangan, kaki, serta kuku. 
Faktor yang mempengaruhi personal hygiene diantaranya usia, jenis kelamin, status perkembangan, status kesehatan, sosiokultural, sistem pelayanan kesehatan, dan sistem keluarga (Akbar, 2019).

Menurut Notoadmodjo (2014), kebiasaan seseorang dapat mempengaruhi personal hygiene. Ada kebiasaan seseorang yang dapat mempengaruhi kebiasaan tentang kebersihan diri, ada seorang pasien akan jenuh dengan ketidakbersihan dirinya. Hal ini yang membuat seseorang untuk melakukan personal hygiene, atau kebiasaan menggunakan produk tertentu dalam perawatan dirinya seperti penggunaan sabun, dan shampo, agar dirinya tetap bersih dan sehat.

Personal hygiene atau kebersihan diri ini diperlukan untuk kenyamanan, keamanan dan kesehatan seseorang. Kebersihan diri merupakan langkah awal mewujudkan kesehatan diri. Dengan tubuh yang bersih meminimalkan resiko seseorang terhadap kemungkinan terjangkitnya suatu penyakit, terutama penyakit yang berhubungan dengan kebersihan diri yang buruk. Personal hygiene yang tidak baik akan mempermudah tubuh terserang berbagai penyakit, seperti penyakit kulit, penyakit infeksi, penyakit mulut, dan penyakit saluran cerna atau bahkan dapat menghilangkan fungsi bagian tubuh tertentu sepertinya halnya kulit (Soedarto dalam Saryono, 2011).

Hasil analisis uji statistik didapatkan nilai $p$-value $0,000<0,05$, maka dapat disimpulkan bahwa terdapat hubungan dukungan keluarga dengan personal hygiene pada pasein stroke di Rumah Sakit Mitra Husada Pringsewu Tahun 2020. Dalam teori Orem keluarga dapat melakukan atau menjalankan perawatan diri yang meliputi sikap mengenai kesehatan mereka dan kemampuan mereka untuk melaksanakan perilaku perawatan diri (Friedman, 2010). Faktor yang mempengaruhi personal hygiene menurut Orem dipengaruhi oleh usia, jenis kelamin, status perkembangan, status kesehatan, sosiokultural, sistem pelayanan kesehatan , sistem keluarga, pola hidup, lingkungan, dan ketersediaan sumber (Akbar, 2019).

Penelitian sebelumnya oleh Rahmantika (2017), di Ruang Kenanga RS dr. Soeparun Malang, menjelaskan bahwa keluarga merupakan sistem pendukung utama pemberi pelayanan langsung pada setiap keadaan terutama penderita stroke yang membutuhkan dukungan orang lain 
terutama keluarga dalam memenuhi kebutuhan kebersihan diri ( $p$-value $0.00<$ 0,05). Hal ini menunjukan bahwa dukungan keluarga sangat berpengaruh terhadap personal hygiene pada pasien stroke.

Friedman (2014), menyatakan bahwa pada pasien stroke dimana keadaan fisiknya tidak lagi seperti saat sehat tetapi keadaan fisiknya sudah mengalami keterbatasan. Dalam hal ini pasien stroke perlu mendapatkan dukungan keluarga supaya personal hygienenya dapat berjalan dengan baik. Dukungan keluarga memainkan peran penting dalam mengintensifkan perasaan sejahtera, orang yang hidup dalam lingkungan yang supportif kondisinya jauh lebih baik dari pada mereka yang tidak memilikinya. Dukungan tersebut akan tercipta bila hubungan interpersonal diantara mereka baik, ikatan kekeluargaan yang kuat sangat membantu ketika keluarga menghadapi masalah karena keluarga adalah orang yang paling dekat hubungannya dengan anggota keluarganya.

Adanya dukungan keluarga yang baik maka personal hygiene pada pasien stroke akan terpenuhi. Jika dukungan keluarga kurang, maka personal hygiene pada pasien stroke akan kurang, pada pasien stroke tidak mampu untuk beraktifitas seperti orang lain lakukan. Hal ini di benarkan oleh Haryati (2007), Pasien stroke tidak mampu bergerak bebas sehingga memerlukan dukungan dalam memelihara personal higiene. Pengaruh langsung dari immobilisasi salah satunya tidak terpenuhinya personal higiene karena terbatasnya kemampuan untuk memenuhinya. Dengan membantu memelihara kebersihan perorangan bermanfaat untuk mencegah penyakitpenyakit tertentu akibat dari penekanan tubuh yang terlalu lama sehingga vaskularisasi ke area takanan terganggu/terhenti. Selain itu dengan membantu memelihara kebersihan perorangan pada pasien stroke dapat membantu mencegah terjadinya luka pada jaringan menjadi nekrosis yang disebut dekubitus dan mencegah terjadinya beberapa penyakit nosokomial serta mencegah berlanjutnya keadaan immobilitas seseorang.

Menurut Dorothea Orem, Personal hygine / perawatan diri adalah kegiatan memenuhi kebutuhan dalam mempertahankan kehidupan, kesehatan dan kesejahteraan individu baik dalam keadaan sehat maupun sakit. Perawatan diri 
berdasarkan Orem Pada dasarnya semua manusia mempunyai kebutuhan untuk melakukan perawatan diri dan mempunyai hak untuk melakukan perawatan diri secara mandiri, kecuali bila orang itu tidak mampu. Model Orem dapat diperluas hingga keluar dari parameter awal yaitu perawatan diri individu menjadi perawatan keluarga (Akbar, 2019).

Faktor yang mempengaruhi personal hygiene salah satunya adalah sistem keluarga yang meliuputi dukungan keluarga. Teori Orem menjelaskan bahwa keluarga dalam melakukan atau menjalankan perawatan diri yang meliputi sikap mengenai kesehatan mereka dan kemampuan mereka untuk melaksanakan perilaku perawatan diri (Friedman, 2010).

Menurut Sarwono (2011) dukungan adalah suatu upaya yang diberikan kepada orang lain, baik moril maupun materil untuk memotivasi orang tersebut dalam melaksanakan kegiatan. Dukungan keluarga juga didefinisikan sebagai informasi verbal atau non verbal, saran, bantuan yang nyata atau tingkah laku yang diberikan oleh orangorang yang akrab dengan subjek di dalam lingkungannya atau yang berupa kehadiran dan hal-hal yang dapat memberikan keuntungan emosional dan berpengaruh pada tingkah laku penerimanya. Dalam hal ini orang yang merasa memperoleh dukungan secara emosional merasa lega karena diperhatikan, mendapat saran atau kesan yang menyenangkan pada dirinya.

Salah satu faktor yang mempengaruhi kebutuhan perawatan diri menurut Orem adalah sistem keluarga yaitu keluarga dapat melakukan atau menjalankan perawatan diri yang meliputi sikap mengenai kesehatan mereka dan kemampuan mereka untuk melaksanakan perilaku perawatan diri, hal tersebut yang menjadikan dukungan keluarga dibutuhkan apabila individu tidak dapat melakukan pemenuhan kebersihan diri (Friedman, 2014). Hasil analisis penelitian diketahui dari 69 responden jika dukungan keluarga kurang maka personal hygiene juga akan kurang baik yaitu 32 responden (94,1\%), sedangkan bila dukungan keluarga baik maka personal hygiene akan baik juga yaitu sebesar 34 responden (97,1\%).

Dari analisis penelitian didapatkan ada 1 responden yang tidak mendapatkan dukungan keluarga tetapi personal hygiene baik, dan ada 2 responden yang mendapatkan dukungan keluarga baik tetapi personal hygiene kurang baik, hal ini bisa disebabkan 
dari berat ringannya kondisi pasien dan kebiasaan. Ada kebiasaan seseorang yang dapat mempengaruhi kebiasaan tentang kebersihan diri, ada seorang pasien akan jenuh dengan ketidakbersihan dirinya (Notoadmodjo, 2014).

Hal ini membuktikan bahwa seseorang dengan dukungan keluarga yang baik akan lebih bisa memenuhi kebutuhan perawatan diri dibanding dengan yang memiliki dukungan keluarga kurang. Dukungan keluarga dapat memperkuat setiap individu, menciptakan kekuatan keluarga, memperbesar penghargaan terhadap diri sendiri, sehingga pasien stroke menjadi lebih nyaman untuk mempertahankan dan melakukan pemenuhan kebersihan diri.

Selain itu dukungan yang diberikan keluarga dapat berupa dukungan informasional, karena keluarga merupakan sumber informasi bagi pasien, keluarga yang selalu mencari tahu dan menanyakan setiap perkembangan kondisi pasien pada tenaga kesehatan di rumah sakit. Selanjutnya dapat berupa dukungan penghargaan atau penilaian, yaitu keluarga bertindak membimbing dan memberi pujian kepada pasien untuk melakukan pemenuhan kebersihan diri. Keluarga juga dapat memberi dukungan instrumental yaitu mempersiapkan kebutuhan peralatan pasien ketika pasien melakukan kebersihan diri maupun berhias diri, serta keluarga senantiasa memberikan dukungan emosional berupa memberi semangat kepada pasien untuk melakukan personal hygiene (Friedman , 2013).

Kesadaran keluarga sangat tinggi akan pentingnya dukungan emosional kepada anggota keluarga yang sakit, karena dukungan emosional yang diberikan keluarga dapat mempengaruhi sikap dan perilaku tertentu. Menurut Friedman (2013), keluarga sebagai tempat yang aman dan damai untuk istirahat dan pemulihan serta membantu penguasaan terhadap emosi. Aspek-aspek dari dukungan emosional meliputi dukungan yang diwujudkan dalam bentuk afeksi, adanya kepercayaan, perhatian, mendengarkan dan didengarkan. Dukungan emosional keluarga kepada pasien stroke sangat diperlukan untuk membuat pasien stroke merasa nyaman, yakin, dipeduli, dan dicintai oleh keluarga.

Berdasarkan hasil analisis penelitian, maka peneliti memberikan kesimpulan bahwa agar terpenuhinya personal hygiene pada pasien stroke tidak cukup hanya dengan 
dukungan dan pengertian dari seluruh anggota keluarga tetapi juga tergantung dari parah atau tidaknya serangan stroke, kondisi tubuh penderita, ketaatan penderita dalam menjalani proses penyembuhan, ketekunan dan semangat penderita untuk sembuh. Sering kali ditemui bahwa penderita stroke yang kurang mendapatkan dukungan keluarga mendapatkan masalah penyakit lain akibat tidak terpenuhinya personal hygiene serta kurangnya dukungan keluarga.

Menurut peneliti perawat juga harus turut andil dalam personal hygiene pasien, dengan cara memberikan edukasi kepada keluarga dan pasien tentang pentingnya personal hygiene dan dampak buruk apabila kebersihan diri tidak dilakukan, serta keluarga dapat memberikan dukungan lebih maksimal lagi dalam proses perawatan seperti dukungan emosional seperti memberi suasana nyaman, memberikan pujian serta perhatian, dukungan penghargaan seperti memberikan semangat dan pujian, dukungan instrumental seperti menyediakan waktu dan menyediakan sarana dan prasarana,dukungan spiritual, serta dukungan informasi seperti memberikan informasi tentang perilaku yang memperburuk kondisi pasien. Karena dukungan keluarga kurang baik akan menyebabkan personal hygiene yang kurang baik sedangkan bila dukungan keluarga baik maka personal hygiene akan baik juga.

\section{KESIMPULAN DAN SARAN}

Lebih dari sebagian besar responden berumur $\geq 61$ tahun, yaitu 40 respoden (58.0\%), berjenis kelamin laki-laki 38 respoden $(55,1 \%)$, berpendidikan SD 45 responden $(65,2 \%)$ dan 30 responden (43,5\%) bekerja sebagai petani. Sebagian besar responden mendapatkan dukungan keluarga dengan kategori baik yaitu 35 responden (50,72\%). Sebagian besar personal hygiene pasien dalam kategori baik yaitu sebesar 36 responden (52,2\%). Ada hubungan dukungan keluarga dengan personal hygiene pada pasein stroke di Rumah Sakit Mitra Husada Pringsewu Tahun 2020 dengan nilai p-value 0.000 .

Petugas kesehatan/perawat hendaknya bisa menjadi edukator, fasilitator dengan pemberian informasi yang berkaitan dengan kebersihan diri (personal hygiene) dan pemberian asuhan keperawatan secara komprehensif dengan melibatkan peran serta aktif keluarga.

Keluarga dapat memberikan dukungan lebih maksimal lagi dalam proses perawatan seperti dukungan emosional seperti memberi suasana nyaman, memberikan pujian serta perhatian, 
dukungan penghargaan seperti memberikan semangat dan pujian, dukungan instrumental seperti menyediakan waktu dan menyediakan sarana dan prasarana, dukungan informasi seperti memberikan informasi tentang perilaku yang memperburuk, serta dukungan spiritual. Penelitian ini diharapkan dapat memberikan informasi kepada masyarakat umumnya dan keluarga pasien bahwa dukungan yang diberikan, kondisi kesehatan, ekonomi dan kondisi kejiwaan dapat mempengaruhi personal hygiene pasien stroke.

Pasien hendaknya dapat melatih kekuatan otot dengan terapi dan kontrol secara rutin sehingga secara perlahan pasien dapat menjaga personal hygiene sesuai dengan batas kemampuan.

\section{DAFTAR PUSTAKA}

Akbar, Agung, M. 2019. Konsep- Konsep Dasar dalam Keperawatan Komunitas. E Book

Arikunto, Suharsimi.2010. Prosedur Penelitian suatu Pendekatan Praktik. Jakarta: Pt. Rineka Cipta

Aziz alimul hidayat dan Musrifatul Uliyah. (2014).Pengantar Kebutuhan Dasar Manusia Edisi 2. Jakarta : Salemba Medika.

Balitbang Kemenkes RI., 2013. Riset Kesehatan Dasar; RISKESDAS. Jakarta: Balitbang Kemenkes RI
Brunner \& Suddarth. 2010. Keperawatan Medical Bedah Edisi 8 Volume 1. Jakarta : EGC

Chindy $M, 2016$. Dukungan keluarga dalam memenuhi kebersihan diri pada penderita stroke ( CVA) yang mengalami gangguan motorik.jurnal penelitian

dr. Iskandar Junaidi, (2011) Stroke Waspadai Ancamanya : Panduan Stroke Paling Lengkap.Yogyakarta: ANDI

dr.Rizaldy Pinzon, (2010)Awas Stroke : Pengertian, Gejala, Tindakan, perawatan,\& Pencegahan. Yogyakatra: ANDI

dr.Sri B, Dkk. 2017. Buku Ajar Neurologi. Malang : Sagung Seto

Friedman, M.M, dkk., 2010. Keperawatan Keluarga : Teori dan Praktik. Jakarta:Salemba Medika

Friedman. (2013). Keperawatan Keluarga. Yogyakarta: Gosyen Publishing

Friedman. (2014). Buku Ajar Keperawatan Keluarga Riset, Teori, \& Praktik : ECG

Goldszmidt, A.J, dan Louis R.K, Stroke Esensial: Edisi Kedua (Jakarta: Indeks permata putri, 2013). Halaman 133-135. (Buku elektronik).

Mubarak, CN. (2010). Buku ajar kebutuhan dasar manusia : Teori, Aplikasi dan Praktik. Jakarta :EGC.

Naziah ,dkk . 2019. Hubungan Dukungan Keluarga Dengan Perwatan Diri (Self Care) Pasien Dengan Strke Non Hemoragik di Ruang Rawat Inap Rs Islam Cempaka Putih Tahun 2018, jurnal ilmu keperawatan dan kebidanan nasional.

Notoatmodjo, S. 2010. Metodologi Penelitian Kesehatan. Jakarta : Rineka Cipta

Nursalam. (2013). Konsep dan Penerapan metdologi penelitian ilmu keperawatan. Jakarta : Salemba Medika. 
Potter \& Perry. (2010). Fundamental Of Nursing Edisi 7. Jakarta : Salemba Medika.

Price \& Wilson. 2010. Patosiologi Konsep Klinis Proses-proses penyakit.Jakarta :EGC

Pudiastuti, R.D., 2011. Penyakit Pemicu Stroke. Yogyakarta: Nuha Medika

Rahmatika S, dkk. 2017. Hubungan Dukungan Keluarga Dengan Pelaksanaan Personal Hygiene Pada Pasien Stroke di Ruang Kenanga Rumah Sakit DR. Soeparun Malang. Nursing News

Siti R, Dkk. 2017. Hubungan dukungan keluarga dengan pelaksanaan personal hygiene pada pasien stroke di ruang kenanga rumah sakit Dr. soeparoen malang, jurnal penelitian

Sulistyo, A. and I. Laily (2012). PERSONAL HYGIENE Konsep, Proses, dan Aplikasi dalam Praktik Keperawatan, graha ilmu, Yogyakarta

Sugiyono (2017). Metode Penelitian Kuantitatif, Kualitatif, dan R\&D , Bandung: Alfabeta

Tantut Susanto.2012. Buku Ajar Keperawatan Keluarga: aplikasi teori pada praktik Asuhan Keperawatan Keluarga, Jakarta :TIM

Tarwoto \& Wartonah.(2015). Kebutuhan Dasar Manusia dan Proses Keperawatan. Jakarta : Salemba Medika.

Tutu April Ariani (2012).Sistem Neurobehaviour, Jakarta : Salemba Medika

Wahid I, Dkk. 2015. Buku Ajar IImu Keperawatan Dasar. Jakarta : Salemba Medika

Wurtiningsih, Budi. 2012. Dukungan Keluarga pada Pasien Stroke di Ruang Rawat Saraf RSUP Dr. Kariadi Semarang. Jurnal Medica Hospitalia. Vol 1. No. 1 